MARINADE Vol. 03(01) : $22-36$ (April 2020)

e-ISSN : 2654-4415

online : http://ojs.umrah.ac.id/index.php/marinade

\title{
PEMANFAAT AN AIR LIMBAH REBUSAN IKAN TAMBAN (Sardinella sp.) SEBAGAI FLAVOR PASTA ALAMI
}

\author{
Utilization Of Additional Fish Wastewater (Sardinella sp.) As Natural Pasta Flavor \\ Muhamad Syahrul Syah'), Azwin Apriandi'2), R. Marwita Sari Putri3) \\ ${ }^{1}$ Program Studi Teknologi Hasil Perikanan, Fakultas IImu Kelautan dan Perikanan \\ Universitas Maritim Raja Ali Haji
}

Korespondensi: Syasyah98@gmail.com

Diterima : 16 Februari 2020; Disetujui : 28 Maret 2020

\begin{abstract}
The aims of this study was to determine the effect of temperature on the level of preference of panelists resulting from flavor paste. This research is an experimental laboratories with a completely randomized design of one factor, namely wastewater boiled fish is treated with different temperatures with a temperature of $70^{\circ} \mathrm{C}, 75^{\circ} \mathrm{C}, 80^{\circ} \mathrm{C}, 85^{\circ} \mathrm{C}, 90^{\circ} \mathrm{C}$. Then analyzed using SPSS 25 to obtain the best treatment. The results of the experiment showed that falvor paste given different treatment gave a significant difference $(\rho<0,05 \%)$ to the panelist preference level. Based on the results of the chemical analysis test that is obtained $0.76 \%$ protein content, $62.44 \%$ water content, $13.42 \%$ ash content, $22.94 \%$ carbohydrate. while for the amino acids obtained with the highest value, Tyrosine $0.18 \%$, the lowest value is Serin $0.5 \%$ in the best flavor paste with the F3 code. The raw material used in making flavors is also tested by heavy metals but not detected.
\end{abstract}

Keywords: Amino acids, flavor, heavy metals, proximate, temperature.

\begin{abstract}
ABSTRAK
Tujuan penelitian ini untuk mengetahui pengaruh suhu terhadap tingkat kesukaan panelis hasil flavor pasta. Penelitian ini bersifat experimental laboratories dengan rancangan acak lengkap satu faktor, yaitu air limbah rebusan ikan tamban diberi pelakuan suhu yang berbeda dengan suhu $70^{\circ} \mathrm{C}, 75^{\circ} \mathrm{C}, 80^{\circ} \mathrm{C}, 85^{\circ} \mathrm{C}, 90^{\circ} \mathrm{C}$. Kemudian di analisis menggunakan SPSS 25 untuk memperoleh perlakuan terbaik. Hasil percobaan menunjukkan bahwa falvor pasta yang diberikan perlakuan berbeda memberikan perbedaan yang nyata $(\rho<0,05 \%)$ terhadap tingkat kesukaan panelis. Berdasarkan hasil uji analisis kimia yaitu diperoleh kandungan protein 0,76\%, kadar air 62,44\%, kadar abu $13,42 \%$, karbohidrat 22,94\%. sedangkan untuk asam amino yang diperoleh dengan nilai tertinggi yaitu Tirosin $0,18 \%$, nilai terendah yaitu Serin $0,5 \%$ pada flavor pasta terbaik dengan kode F3. Bahan baku yang digunakan dalam pembuatan flavor ini juga dilakukan uji logam berat namun tidak terdeteksi.
\end{abstract}

Kata Kunci: Asam amino, flavor, logam berat, proksimat, suhu. 


\section{PENDAHULUAN}

Kepulauan Riau memiliki hamparan pesisir pantai yang luas dengan luas wilayah $251.810 .71 \mathrm{Km}^{2}$ terdiri dari lautan $241.2153 \mathrm{Km}^{2}$, masyarakat pesisir mayoritas bekerja sebagai nelayan tangkap, hasil limbah air perebusan yang dihasilkan setiap harinya juga terus meningkat seiring dengan banyaknya hasil tangkapan. Tingginya kandungan protein pada ikan tamban yaitu berkisar $40.68 \pm 0.42 \%$ sehingga sangat memungkinkan pada air yang digunakan pada saat perebusan juga memiliki kandungan protein terlarut, dengan demikian perlu dilakukan pengujian kimia untuk mengetahui kandungan protein dengan membuatnya sebagai produk hasil samping (Miranti dan Putra 2019).

Ikan tamban (Sardinella sp.) merupakan ikan pelagis yang terdapat di perairan indo-pasifik. Tamban ialah salah satu hasil perikanan tangkap yang ada di kepulauan riau. Kondisi ikan yang kecil sehingga perlu dilakukan penangan secara intensif agar kemunduran mutu ikan dapat dihambat. Upaya yang dilakukan oleh nelayan penghasil tamban yaitu dengan melakukan perebusan dilaut ataupun dipesisir sebelum dilakukan pengeringan.

Flavor merupakan pembangkit cita rasa yang muncul karena adanya sensasi bagi yang mengkonsumsinya, selain itu juga karena adanya komponen ekstraktif non-volatil yang dapat membangkitkan cita rasa yaitu berupa asam amino bebas karena didalamnya terdapat asam glutamat yang dapat membangkitkan cita rasa bagi produk perikanan (Pratama et al. 2018). Inovasi penyedap masakan selain kaldu dan kecap, juga berupa garam sedap. Dengan asumsi kebutuhan minimal garam konsumsi sebesar 3 $\mathrm{kg} /$ tahun/kapita, maka apabila jumlah penduduk Indonesia \pm 250 juta, kebutuhan garam konsumsi sebesar 750.000 ton/tahun. Untuk itu penggunaan garam sedap sebagai penyedap masakan sangat dibutuhkan, karena bahan dasar tersedia dan pangsa pasar cukup besar (Witono et al. 2017).

Tingginya tingkat kebutuhan flavor maka limbah air perebusan ikan tamban ini diharapkan mampu menjadi solusi untuk memnuhi kebutuhan pasar dengan mengkonsumsi flavor pasta alami, Bahan yang sering digunakan Terdapat jenisjenis bahan pembangkit cita rasa umum yakni asam amino $L$ dan / atau garamnya (dikenal sebagai MSG), dan jenis 5'nukleotida (dikenal sebagai 5'-IMP dan 5'GMP) kedua bahan ini sering digunakan dalam pembuatan umami. Penggunaan MSG pada makanan yang dikonsumsi sering mengganggu kesehatan karena MSG ketika dimakan akan terurai menjadi sodium dan glutamat sehingga MSG merupakan sumber natrium yang tinggi (Mega 1998; Witono et al. 2017). Seiring dengan tingginya kebutuhan konsumen akan flavor dan semakin melimpahnya air limbah perebusan maka perlu dilakukanya inovasi baru dengan membuat penelitian pemanfaatan air limbah rebusan ikan tamban sebagai flavor pasta alami. diharapkan produk ini dapat memenuhi kebutuhan pasar sebagai pengganti produk komersil dan dapat mengatasi limbah dilingkungan.

\section{BAHAN DAN METODE}

\section{Bahan dan Alat}

Bahan utama yang digunakan adalah air limbah rebusan ikan tamban yang diperoleh dari Desa Pangkil Kabupaten Bintan Kota Tanjungpinang, Bumbu yang digunakan untuk pembuatan penyedap masakan yaitu bawang merah, bawang putih, gula halus, cabe rawit, xantan gum, 
dan air. xantan gum digunakan Sebagai bahan pengental.. Bahan untuk analisis proksimat adalah aquades, kjeldal, $\mathrm{N}_{2} 2 \mathrm{~B}_{4} \mathrm{O}_{7} \cdot 10 \mathrm{H}_{2} \mathrm{O}, \mathrm{NaOH}, \mathrm{HCl} 0,2 \mathrm{~N}$, $\mathrm{H}_{2} \mathrm{SO}_{4}$ pekat, indikator $\mathrm{MM} 0,1 \%$, selenium, kapas bebas lemak, dan pelarut lemak (n-heksana p.a), $\mathrm{HCl} 25 \%$. Bahan untuk analisis asam amino yaitu $\mathrm{HCl} 6 \mathrm{~N}$, akuabides, metanol, picoltiocianat (PITC), triethylamine (TEA), natrium asetat, buffer natrium asetat $1 \mathrm{M}$ dan asetonitril. Bahan untuk uji kandungan logam berat yaitu Air limbah rebusan ikan tamban, $\mathrm{HNO}_{3}, \mathrm{H}_{2} \mathrm{SO}_{4}$ dan $\mathrm{HCl}$.

Alat yang digunakan dalam penelitian ini adalah timbangan digital, pisau, sendok, kompor, panci, kuali, corong, penapis, Botol pengemas, botol kaca, blender, spatula, kertas label, tisu, gelas ukur, thermo laser, gelas ukur, nampan, penjepit makanan, toples, wadah kecil untuk nimbang. Alat yang digunakan dalam analisis kandungan logam berat adalah Inductively Coupled Plasma Optical Emission Spectrometry (ICPOES). Alat yang digunakan untuk proses perebusan adalah panci dan pemanas. Alat yang digunakan untuk analisis kandungan asam amino adalah oven, vial head space, labu ukur $50 \mathrm{ml}$, timbangan analitik ketelitian $0,1 \mathrm{mg}$, kertas sating grade 42 , syringe filter GHP/RC 0,2 $\mu \mathrm{m}$, pipet $500 \mu \mathrm{L}$, tube $2 \mathrm{~mL}$, heating block, UPLC H-Class.

\section{Metode}

Metode penelitian ini menggunakan metode experimental laboratoris, yang memiliki 5 perlakuan dengan perbedaan suhu $70^{\circ} \mathrm{C}, 75^{\circ} \mathrm{C}, 80^{\circ} \mathrm{C}, 85^{\circ} \mathrm{C}, 90^{\circ} \mathrm{C}$. Hasil uji organoleptik dianalisis menggunakan SPSS 25 untuk meperoleh perlakuan terbaik dengan melakukan uji Kruskawalis-test, bila terdapat perbedaan yang nyata maka dilakukan uji lanjut
Duncan. yang kemudian di uji proksimat dan asam amino. air limbah rebusan ikan tamban juga dilakukan uji logam berat.

\section{Prosedur Penelitian}

Penelitian ini dilakukan dengan beberapa tahapan, tahap pertama yaitu pengambilan sampel. Tahap kedua yaitu persiapan formulasi flavor pasta ikan tamban, dan tahap ketiga yaitu analisis flavor pasta terbaik berdasarkan organoleptik untuk dilakukan analisis kimia.

\section{Pengambilan Sampel}

Sampel penelitian ini diambil dari Kecamatan Teluk Bintan, Desa Pangkil Dusun Tanjungkramat. Pengambilan sampel dengan menggunakan 2 transpotasi untuk menuju kelokasi, yaitu transportasi kapal laut dan kendaraan darat berupa motor. Sampel diambil kemudian dimasukan kedalam botol kaca yang sudah disterilkan untuk dibawa kedalam Laboratorium Pengolahan Fakultas IImu Kelautan Perikanan.

\section{Formulasi Flavor}

Sebelum dilakukan pengolahan maka perlu dilakukanya Sterilisasi alat yang akan digunakan dalam proses formulasi, kemudian mempersiapkan bumbu yang akan digunakan seperti bawang merah, bawang putih, cabe rawit dan xantan gum. selanjutnya dilakukan penimbangan bahan yang kemudian dihomogenkan menggunakan blender dengan penambahan air. Pemansan air limbah perebusan ikan tamban dan pencampuran bahan tambahan dengan suhu pemanasan yang berbeda-beda yaitu pada suhu $70,75,80,85,90{ }^{\circ} \mathrm{C}$ dengan menggunakan waktu pemanasan yang sama yaitu 25 menit. Setelah itu flavor pasta dikemas untuk dilakukan uji organoleptik setelah terpilih yang terbaik 
akan dilakukan uji kimia seperti uji proksimat, asam amino dan viskositas.

Tabel 1. Formulasi flavor pasta air limbah rebusan ikan tamban

\begin{tabular}{clc}
\hline \multirow{2}{*}{ No } & \multicolumn{1}{c}{ Bahan } & Persentase \\
\cline { 2 - 3 } & & $(\%)$ \\
\hline 1 & Air limbah & 52,2 \\
& rebusan ikan & \\
& tamban & \\
2 & Air & 39,1 \\
3 & Bawang merah & 1,6 \\
4 & Bawang putih & 1,6 \\
5 & Cabe rawit & 0,2 \\
6 & Gula & 5 \\
7 & Xantan gum & 0,3 \\
\hline Total & & 100 \\
Sumber: & Modifikasi BBP2HP $(2019)$
\end{tabular}

Uji Organoleptik (SNI 01-2346-2006)

Uji organoleptik berfungsi untuk mengukur tingkat kesukaan panelis terhadap sampel dengan menggunakan lembar penilaian. Pada uji organoleptik, tingkat kesukaan panelis bervariasi tergantung rentangan mutu yang ditentukan. Penilaian uji organoleptik pada penelitian ini meliputi warna, aroma, rasa, dan tekstur dengan 30 orang panelis yang kemudian dianalisis dengan menggunakan uji kruskalwallis-test dan Duncan untuk penarikan kesimpulan.

\section{Analisis Kimia Flavor Terpilih}

Analisis kimia meliputi uji proksimat pada flavor yang terdiri dari kadar air, kadar abu, kadar lemak, dan kadar protein.

\section{Kadar Air}

Analisis kadar air dilakukan dengan menggunakan metode (SNI-01-28911992). Prinsipnya kehilangan bobot pada pemanasan $105{ }^{\circ} \mathrm{C}$ dianggap sebagai kadar air yang terdapat pada contoh. Sebanyak 1-2 g contoh dimasukkan kedalam cawan alumunium yang telah diketahui bobotnya. Cawan yang berisi contoh kemudian dikeringkan pada oven suhu $105^{\circ} \mathrm{C}$ selama 3 jam, setelah itu cawan didinginkan dalam desikator dan ditimbang. Pengeringan diulangi hingga diperoleh bobot tetap.Perhitungan kadar air adalah sebagai berikut :

$$
\operatorname{Kadar} \operatorname{Air}(\%)=\frac{((\mathrm{A}+\mathrm{B})-\mathrm{C})}{\mathrm{B}} \times 100 \%
$$

Keterangan:
A :berat wadah kosong $(\mathrm{g})$
$B$ :berat sampel $(\mathrm{g})$
C :Berat tetap wadah + sampel setelah pemanasan $(\mathrm{g})$

\section{Kadar Abu}

Analisis kadar abu dilakukan menggunakan metode (SNI-01-28911992). Prinsipnya adalah pada saat pengabuan zat-zat organik diuraikan menjadi air dan $\mathrm{CO} 2$, tetapi bahan-bahan organik tidak. Sebanyak 2-3 g contoh dimasukkan ke dalam sebuah cawan porselin yang telah diketahui bobotnya. Untuk sampel bentuk cairan, contoh diuapkan diatas penangas air sampai kering. Cawan yang berisi sampel selanjutnya diarangkan diatas nyala pembakar, lalu diabukan dalam tanur listrik pada suhu maksimum $550{ }^{\circ} \mathrm{C}$ sampai pengabuan sempurna. Kemudian cawan didinginkan dalam desikator dan ditimbang. Perhitungan kadar abu adalah sebagai berikut :

$$
\text { Kadar Abu (\%) }=\frac{\mathrm{C}-\mathrm{A}}{\mathrm{B}} \times 100 \%
$$

Keterangan:
A : berat wadah kosong $(\mathrm{g})$
$B$ : berat sampel $(\mathrm{g})$
C : berat contoh + cawan setelag
diabukan $(\mathrm{g})$ 


\section{Kadar Protein}

Analisis kadar protein dilakukan dengan metode (SNI-01-2891-1992). Prinsipnya adalah senyawa nitrogen diubah menjadi amonium sulfat oleh $\mathrm{H}_{2} \mathrm{SO}_{4}$ pekat. Amonium sulfat yang terbentu diuraikan dengan $\mathrm{NaOH}$. Amoniak yang dibebaskan diikat dengan asam borat dan kemudia dititar dengan larutan baku asam. Timbang seksama 0,51 - $1 \mathrm{~g}$ contoh, masukkan kedalam labu kjeldahl $100 \mathrm{ml}$. Tambahkan $2 \mathrm{~g}$ campuran selen dan $25 \mathrm{ml} \mathrm{H}_{2} \mathrm{SO}_{4}$ pekat, kemudian panaskan di atas pemanas listrik atau api pembakar sampai mendidih dan larutan menjadi jernih kehijau-hijaun (sekitar 2 jam), biarkan dingin kemudian encerkan dan masukkan ke dalam labu ukur $100 \mathrm{ml}$, tepatkan sampai tanda garis, pipet $5 \mathrm{ml}$ larutan dan masukkan ke dalam alat penyuling tambahkan $5 \mathrm{ml}$ $\mathrm{NaOH} 30 \mathrm{~g}$ dan beberapa tetes indikator PP, setelah itu sulingkan selama lebih kurang 10 menit, sebagai penampung gunakan $10 \mathrm{ml}$ larutan asam borat $2 \%$ yang telah dicampur indikator, bilasi ujung pendingin dengan air suling, titar dengan larutan $\mathrm{HCl} 0,001 \mathrm{~N}$, selanjutnya kerjakan penetapan blanko. Perhitungan kadar protein adalah sebagai beruikut :

$$
\text { Protein }(\%)=\frac{(\mathrm{Vs}-\mathrm{Vb}) \times \mathrm{Nx} 1,4007 \mathrm{xFk}}{\text { Bobot sampel }} \times 100 \%
$$

Keterangan :

Vs : Volume $\mathrm{HCl} 0.2 \mathrm{~N}$ yang diperlukan untuk titrasi sampel $(\mathrm{mL})$

$\mathrm{Vb}$ : Volume $\mathrm{HCl} 0.2 \mathrm{~N}$ yang diperlukan untuk titrasi blanko $(\mathrm{mL})$

$\mathrm{N}$ : Normalitas larutan $\mathrm{HCl} 0.2 \mathrm{~N}$

Fk : Faktor konversi protein

\section{Kadar Lemak}

Analisis kadar lemak dilakukan dengan metode (SNI-01-2891-1991). Prinsipnya adalah ekstraksi lemak bebas dengan pelarut non polar. Timbang 1-2 gram sampel ke dalam piala gelas $100 \mathrm{~mL}$, kemudian ambahkan $30 \mathrm{~mL} \mathrm{HCl} 25 \%$ dan $20 \mathrm{~mL}$ akuades serta beberapa batu didih, selanjutnya utup piala gelas dengan kaca arloji, lalu didihkan selama 15 menit di atas hot plate. Saring residu dalam keadaan panas menggunakan kertas saring berabu, lalu cuci residu dengan akuades panas hingga bebas asam. Keringkan residu dalam oven pada suhu 100-105 ${ }^{\circ} \mathrm{C}$ selama 1 jam.

Masukkan ke dalam selongsong kertas saring (hulls) yang telah dialasi dengan kapas, lalu sumbat bagian atas hulls dengan kapas, Masukkan hulls ke dalam alat sokhlet yang telah dihubungkan dengan labu lemak $300 \mathrm{~mL}$ yang berisi batu didih, telah dikeringkan, dan telah diketahui bobotnya, Tambahkan heksana melalui sokhlet hingga setengah volume labu lemak dan seluruh bagian hulls dalam sokhlet terendam, Rangkaikan dengan kondensor dan penangas air, lalu ekstraksi sampel selama 2-3 jam, Sulingkan heksana, lalu keringkan residu lemak dalam oven pada suhu 100 -105 ${ }^{\circ} \mathrm{C}$, Dinginkan labu lemak berisi residu lemak dalam desikator hingga suhu ruang, lalu timbang bobotnya, Ulangi tahap pengeringan dalam oven pada suhu $100-105{ }^{\circ} \mathrm{C}$ hingga tercapai bobot tetap. Perhitungan kadar lemak adalah sebagai berikut :

$$
\text { Kadar Lemak }(\%)=\frac{C-A}{B} \times 100 \%
$$

Keterangan :
$A$ : berat labu lemak kosong $(\mathrm{g})$
$\mathrm{B}$ : berat contoh $(\mathrm{g})$
C : berat labu lemak + sampel setelah pemanasan $(\mathrm{g})$

\section{Karbohidrat by difference}


Perhitungan kadar karbohidrat dilakukan secara by difference, yaitu dengan menggunakan rumus:

Kadar karbohidrat $=100 \%$ - (K.lemak + K.Protein+K.air + K.Abu)

\section{Analisis Kandungan Asam Amino}

Pengujian asam amino dengan metode Ultra Performance Liquid Chromatography (UPLC) Analisis asam amino menggunakan UPLC terdiri beberapa tahap yaitu. Sampel ditimbang sebanyak 0.1-1,0 g kedalam vial head space sebanyak $20 \mathrm{~mL}$. Larutan sampel ditambah $\mathrm{HCl} 6 \mathrm{~N}$ sebanyak $5 \mathrm{~mL}$, dihidrolisis dalam oven pada suhu $110^{\circ} \mathrm{C}$ selama 22 jam, lalu di dinginkan dan dipindahkan ke labu ukur $50 \mathrm{~mL}$. Kemudian bilas tabung head space dan encerkan dengan aquabides sampai tanda batas, lalu homogenkan, selanjutnya saring larutan sampel dengan kertas saring tak berabu grade 42 dan disaring kembali dengan syringe filter GHP/RC 0,2 $\mu \mathrm{m}$, kemudian tambahkan pipet $500 \mu \mathrm{L}$ sampel yang sudah disaring kedalam tube $2 \mathrm{~mL}$, kemudian tambahkan $40 \mu \mathrm{L}$ internal standar AABA 2,5 mM dan $460 \mu \mathrm{L}$ akuabides, voteks tahap beritunya lakukan proses derivatisasi larutan sampel. Tahap proses derivatisasi sampel yaitu, Pipet masingmasing $10 \mu \mathrm{L}$ larutan standar atau sampel yang telah ditambahkan internal standar AABA ke dalam insert vial, tambahkan $70 \mu \mathrm{L}$ Accq. Tag Fluor Borrate Buffer, vortex. Tambahkan $20 \mu \mathrm{L}$ Accq. Tag Reagent $2 A$, vortex, kemudian Panaskan pada heating block dengan suhu $60^{\circ} \mathrm{C}$ selama tepat 10 menit. Selanjutnya angkat, dinginkan sampai suhu ruang, injeksikan larutan ke sistem UPLC. Kandungan asam amino dapat dihitung dengan rumus:
(Rasio analit standar $\times$ C std/1000000000 x bm x fp x 1000) Rasio analit standar $x$ bobot sampel

\section{Analisis Kandungan Logam Berat}

Sampel air limbah rebusan ikan tamban yang telah dilarutkan dilakukan analisis kandungan logam beratnya dengan menggunakan alat ICP-OES (Inductively Coupled Plasma-Optical Emission Spectrometry). Perhitungan logam berat :

$$
\text { Kadar }=\frac{(\text { Intensitas spl-a) } / \mathrm{b} \times \mathrm{V}(\mathrm{ml}) \times \mathrm{fp}}{\mathrm{W} \mathrm{spl} \mathrm{atau} \mathrm{spl}}
$$

Keterangan :

Intensitas spl: Intensitas Sampel

A : Intercept dari kurva kalibrasi standar

b : Slope dari kurva kalibrasi standar

Fp: Faktor pengenceran sampel

$\mathrm{V}$ : Volume labu akhir sampel $(\mathrm{mL})$

\section{HASIL DAN PEMBAHASAN}

\section{Profil Desa Pangkil}

Pangkil merupakan satu diantara banyak pulau yang berada di Kepulauan Riau, Pulau Pangkil terbagi menjadi 2 bagian, yaitu Tanjung Kramat dan Tanjung Kudus dengan jumlah penduduk 1306 jiwa. Mayoritas penduduknya $99,85 \%$ beragama islam dan $29,33 \%$ hanya lulusan Sekolah Dasar. Pekerjaan masayarakatnya mayoritas sebagai seorang nelayan mencapai $23,43 \%$, Luasnya hamparan pantai mempengaruhi tingkat pekerjaan masyarakat sekitar. Kondisi perairan diwilayah ini masih sangat baik karena penduduknya yang tidak terlalu padat, sehingga aktivitas diperaian masih sangat kurang. Masyarakat wilayah ini tergolong kreatif dengan memanfaat hasil perikanan lalu mengolahnya secara tradisional, sehingga tidak merusak ekosistem laut.

\section{Hasil Uji Organoleptik}


Uji organoleptik merupakan salah satu jenis pengujian yang sangat dibutuhkan dalam pembuatan produk pangan, meskipun jenis uji ini tergolong pengujian yang mudah namun memiliki peranan yang sangat penting. pengujian organoleptik ini menggunakan 30 orang panelis semi terlatih sesuai dengan SNI 01-2346-2006.

\section{Warna}

Warna merupakan komponen yang sangat penting untuk diperhatikan, karena akan mempengaruhi sugesti terhadap penerimaan produk yang dihasilkan. dalam penilaian warna menggunakan salah satu alat indra yang sangat berperan penting yaitu indra penglihatan, indera penglihatan akan merespon terhadap direspon oleh saraf sehingga memberikan kesan tersendiri bagi yang melihatnya. Produk bisa saja memiliki rasa enak, dan tekstur yang baik, namun bila warna yang dihasilkan tidak menarik maka produk tersebut tidak akan dipilih oleh konsumen, (Negara et al. 2016).

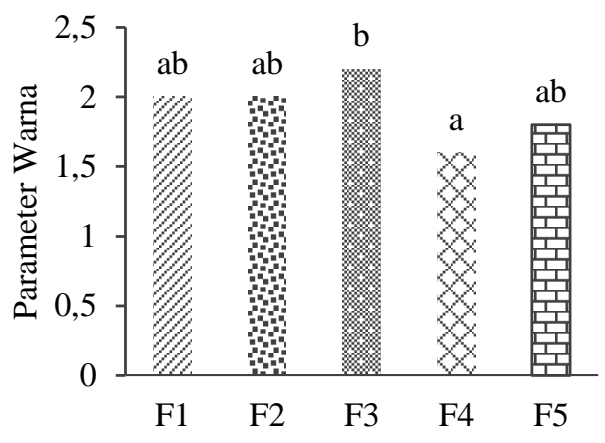

Keterangan: F1: Suhu $70^{\circ} \mathrm{C}$ F4: Suhu $85^{\circ} \mathrm{C}$

F2: Suhu $75^{\circ} \mathrm{C}$ F5: Suhu 90 $\stackrel{\circ}{C}$

F3: Suhu $80 \stackrel{\circ}{ } \mathrm{C}$

Gambar 1. Histogram hasil uji warna

Menurut penelitian Mulyadi et al. (2013), diantara beberapa faktor yang dapat menentukan mutu bahan makanan, warna merupakan faktor penting karena mempengaruhi persepsi awal konsumen. Selain itu warna juga dipengaruhi dari suhu yang diberikan terhadap proses pembuatan flavor, berdasarkan hasil uji terhadap panelis maka semakin tinggi suhu yang diberikan maka akan memberikan pengaruh yang signifikan. untuk itu berdasarkan tingkat kesukaan panelis perlakuan F3 lebih disukai oleh panelis. Suhu yang tinggi akan memberikan warna dari flavor akan semakin gelap dikarenakan terjadinya pencoklatan non enzimatis seperti reaksi maillard, reaksi ini dipengaruhi antara gugus amino dari suatu asam amino bebas residu rantai peptida atau protein dengan gugus karbonil dari suatu karbohidrat apabila keduanya dipanaskan atau penyimpanan dalam waktu lama (Lakshmi 2014).

Berdasarkan Gambar 1. dapat dilihat bahwa perlakuan yang diberikan memberikan hasil yang bervariasi terhadap kesuakan panelis yang kemudian dilakukan uji Kruskawalis-test menunjukan perbedaan secara nyata terhadap masing-masing perlakuan dengan nilai $\rho<0,05$. Kemudian diuji lanjut menggunakan uji Duncan untuk melihat perbedaan dari masing-masing perlakuan.

\section{Aroma}

Aroma merupakan parameter uji yang memanfaatkan indra penciuman yang kemudian dibangun oleh syara-syaraf olfaktori untuk menetukan suatu produk itu enak atau tidaknya, sehingga terbentuknya sugesti panelis untuk menyatakan produk tersebut sesuai dengan keinginan, (Negara et al. 2016). 


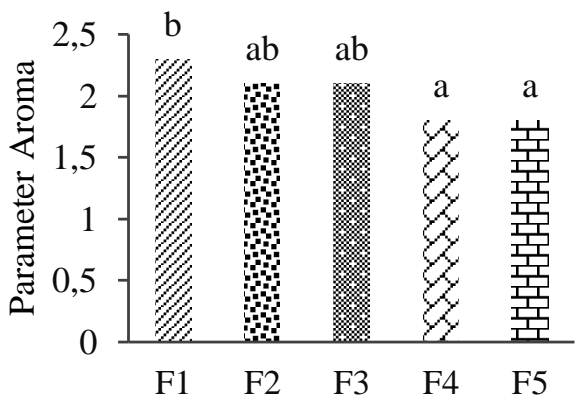

Keterangan: F1: Suhu $70 \stackrel{\circ}{\circ}$ F4: Suhu 85 $\stackrel{\circ}{C}$

F2: Suhu $75^{\circ} \mathrm{C}$ F5: Suhu 90 $\stackrel{\circ}{-C}$

F3: Suhu $80 \stackrel{\circ}{C}$

Gambar 2. Histogram hasil uji aroma

Suhu sangat berperan penting pada setiap perlakuan, karena semakin tinggi suhu yang diberikan maka akan menimbukan aroma yang tidak sesuai harapan. Suhu yang tinggi dalam pembuatan flavor ini memberikan pengaruh yang kurang baik seperti aroma flavor yang berubah dan hasil flavor yang diperoleh juga akan semakin sedikit. Semakin tinggi suhu yang diberikan maka proses penguapan yang terjadi akan semakin cepat, serta kandungan gizi dari flavor juga akan mengalami penurunan, untuk diperlukanya suhu yang optimal (Anggraini dan yunianta 2015).

Berdasarkan Gambar 2. dapat dilihat bahwa perlakuan yang diberikan memberikan hasil yang bervariasi terhadap kesuakan panelis yang kemudian dilakukan uji Kruskawalis-test menunjukan perbedaan secara nyata terhadap masing-masing perlakuan dengan nilai $\rho<0,05$. Kemudian diuji lanjut menggunakan uji Duncan untuk melihat perbedaan dari masing-masing perlakuan.

\section{Rasa}

Rasa merupakan parameter uji yang tidak kalah pentingnya dalam pengujian organoleptik, karena akan mempengaruhi sugesti panelis dalam mengambil keputusan untuk menilai suatu produk. Parameter rasa ini memanfaatkan salah satu alat indra manusia berupa indra pengecap. Lidah manusia akan sangat sensitif bila diberikan berupa rangsangan seperti saat diberikan flavor, secara langsung lidah akan langsung merespon apakah produk tersebut, manis, asin, atau bahakan asam, (Negara et al. 2016).

Setiap individu pasti akan memiliki respon yang berbeda terhadap tingkat sensitivitas indrawinya namun perbedaan itu tidak akan terlalu jauh kergamanya. oleh dari itu diperlukanya panelis yang dalam kondisi baik seperti tidak sakit atau sedang menderita penyakit tertentu agar hasil pengujian tidak terdapat data yang eror.

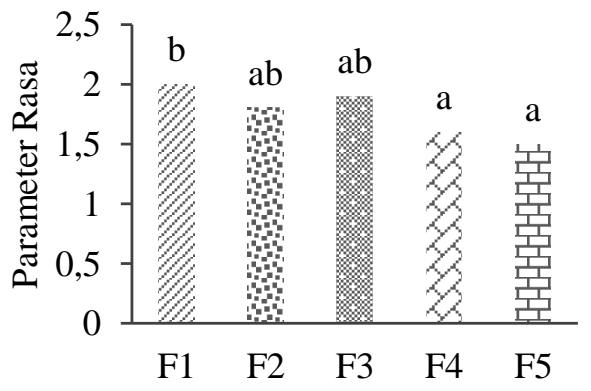

Keterangan: F1: Suhu $70 \stackrel{\circ}{\circ}$ F4: Suhu 85 $\stackrel{\circ}{-C}$

F2: Suhu $75^{\circ} \mathrm{C}$ F5: Suhu 90 $\stackrel{\circ}{\circ}$

F3: Suhu $80 \stackrel{\circ}{\circ}$

Gambar 3. Histogramhasil uji rasa

Adapun bumbu-bumbu pada saat pembuatan formulasi seperti adanya bawang, dan cabe rawit. apabila suhu yang diberikan terlalu tinggi juga dapat merubah rasa dari flavor ini menjadi lebih asin, karena dipengaruhi oleh proses penguapan yang terjadi. semakin tinggi suhu yang diberikan akan semakin banyak proses pengupan yang terjadi 
dan produk yang dihasilkan akan semakin sedikit dan rasa asin akan sangat pekat. Berdasarkan Gambar 3 dapat dilihat bahwa F2 dan F3 memiliki ikatan dari setiap perlakuan sehingga dapat dipilih F3 yang bisa dianggap mewakili dari semua perlakuan berdasarkan uji Kruskawalis-test tidak menunjukan perbedaan secara nyata terhadap masing-masing perlakuan dengan nilai $\rho>0,05$.

\section{Tekstur}

Tekstur merupakan salah satu parameter uji organoleptik flavor pasta yang bertujuan untuk melihat tingkat kekompakan dari flavor yang dihasilkan. pengujian ini menggunakan alat indra penglihatan dan diberikan goyangan sedikit sehingga kita dapat menetukan apakah flavor yang dihasilkan dalam bentuk liquid, pasta atau solid. Tekstur yang dihasilkan juga memberikan pengaruh yang nyata terhadap flavor yang dihasilkan, semakin tinggi suhu yang diberikan maka akan menghasilkan tekstur pasata yang semakin kental.

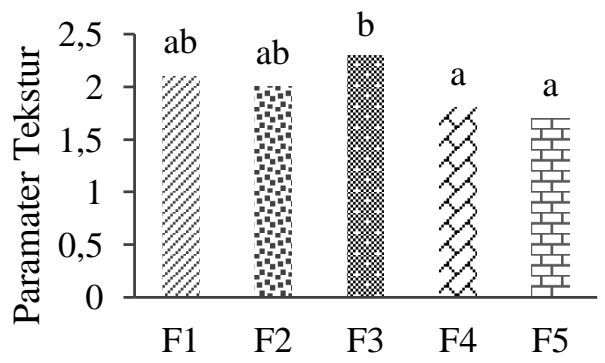

Keterangan: F1: Suhu $70{ }^{\circ} \mathrm{C}$ F4: Suhu 85 $\stackrel{\circ}{C}$

F2: Suhu $75^{\circ} \mathrm{C}$ F5: Suhu 90 $\stackrel{\circ}{C}$

F3: Suhu $80^{\circ} \mathrm{C}$

Gambar 4. Histogramhasil uji tekstur

Proses terjadinya pengentalan ini selain dipengaruhi oleh suhu juga karena adanya penambahan xanthan gum pada saat pembuatan formulasi. Fungsi xanthan gum dalam pembuatan flavor ini yaitu sebagai pengental agar lebih cepat terbentuknya flavor pasta yang dihasilkan. Xanthan gum selain dapat mengefisiensi waktu pembuatan juga dapat memberikan hasil yang maksimal. Suhu yang semakin tinggi menghasilkan flavor yang sangat kental dan hal ini juga mempengaruhi tingkat kesukaan dari panelis. Berdasarkan hasil uji organoleptik ternyata flavor dengan bentuk yang kental kurang diminati oleh panelis. Hal ini disebabkan karena air yang menguap akan semakin banyak dan total padatan terlarut semakin meningkat, sehingga viskositas akan meningkat. Semakin meningkatnya nilai dari hasil viskositas mengakibatkan tekstur produk semakin mengental dan akan berpengaruh terhadap hasil flavor yang diperoleh, (Nilasari et al. 2017). Berdasarkan Gambar 4. dapat dilihat bahwa semakin tinggi suhu yang diberikan maka semakin sedikit panelis yang menyukainya, adapun suhu optimum yang disukai pada parameter tekstur ini yaitu terdapat pada $\mathrm{F} 3$ yaitu dengan suhu $80^{\circ} \mathrm{C}$. Berdasarkan uji Kruskawalis-test menunjukan perbedaan secara nyata terhadap masing-masing perlakuan dengan nilai $\rho<0,05$. Kemudian diuji lanjut menggunakan uji Duncan untuk melihat perbedaan dari masing-masing perlakuan.

\section{Komposisi Kimia Flavor Terpilih}

Komposisi kimia flavor air limbah rebusan ikan tamban salah satunya yaitu dengan mengetahui kandungan gizi kasar melalui uji proksimat, dengan mengetahui kandungan gizi kasar kita akan mengetahui kebutuhan gizi untuk dikonsumsi. Adapun flavor pasta terpilih yaitu perlakuan $\mathrm{F} 3$ dengan suhu $80^{\circ} \mathrm{C}$. Selain itu juga dengan melakukan uji proksimat, kita akan dapat mengetahui 
berapa lama produk akan mampu bertahan terpapar disuhu ruang melalui kandungan kadar air yang terdapat pada flavor yang dihasilkan. Analisis proksimat meliputi kadar air, kadar abu, kadar lemak, kadar protein dan kadar karbohidrat. Berikut merupakan hasil uji proksimat dapat dilihat pada Tabel 2 .

Tabel 2. Hasil uji proksimat Flavor terpilih

\begin{tabular}{lcc}
\hline Parameter & $\begin{array}{c}\text { Hasil Uji } \\
\text { Flavor } \\
\text { Terpilih }\end{array}$ & $\begin{array}{c}\text { Pembanding } \\
\text { Hasil Uji }\end{array}$ \\
\hline Kadar air & $\begin{array}{l}62,44 \\
\pm 0,17\end{array}$ & $66,97^{*}$ \\
& $\begin{array}{l}\text { Kadar abu } \\
13,42 \pm 0,00\end{array}$ & $23,42^{* *}$ \\
Kadar & $0,76 \pm 0,00$ & $8,07^{* *}$ \\
protein & & \\
Kadar & $0,44 \pm 0,00$ & $0,33^{* * *}$ \\
lemak & & \\
karbohidrat & $22,94 \pm 0,17$ & $23,75^{\star * *}$
\end{tabular}

Keterangan: *Pasta nikumi kuda, (Mega 2016)

** Petis dari cairan bandeng, (Fajrita 2016)

*** Air rebusan kepala udang,

\section{Kadar Air}

(Meiyani 2014)

Kadar air merupakan komponen cair yang terdapat dalam flavor air limbah perebusan ikan tamban. Kadar air akan mempengaruhi terhadap kualitas flavor yang dihasilkan. Pada proses ini kadar air berkurang karena terjadinya proses penguapan pada saat pemasakan, Air bebas yaitu air yang terikat secara dispersi pada permukaan makromolekul maupun air yang terikat secara fisik dan kimia, (Viyanti et al. 2019). menurut Nurjanah et al. (2013), perbedaan kadar air ini disebabkan oleh perbedaan perairan tempat biota hidup. Setelah mengaetahui kandungan kadar air maka kita akan mengetahui tingkat kerentanan produk terhadap kerusakan. Kerusakan pada bahan pangan dapat dipengaruhi seperti oleh mikro organisme pathogen maupun jamur, (Bassey et al. 2011). Berdasarkan Tabel 2. dapat dilihat bahwa kandungan air flavor pasta dari air limbah rebusan ikan tamban lebih rendah dibandingkan dengan pasta dari nikumi kuda yaitu dipengaruhi oleh proses pengolahanya, seperti pada nikumi kuda dilakukan sterilisasi pasta pada suhu 121 oC selama 30 menit dalam autoclave.

\section{Kadar Abu}

Kadar abu merupakan bahan-bahan organik yang memiliki kandungan garam mineral dalam produk, kadar abu yang tinggi juga dipengaruhi dari bahan baku yang diperoleh. seperti dipengaruhi habitat biota perairan yang sudah tercemar maupun akibat dari penambahan garam mineral yang digunakan pada saat dilakukan perebusan. Menurut Supriyanti et al. (2013), kadar abu ada hubungannya dengan jumlah mineral dalam suatu bahan. Banyaknya garam yang ditambahkan, maka kadar abu akan semakin tinggi. Semakin banyak garam $\mathrm{NaCl}$ ditambahkan, semakin banyak pula garam anorganik, yang dapat meningkatkan kadar abu, (Suryana et al. 2016). Hasil pengujian kadar abu menunjukan kandungan kadar abu flavor air limbah rebusan ikan tamban lebih rendah dibandingan dengan kadar abu petis dari cairan ikan bandeng hal ini dipengaruhi oleh bahan baku yang digunakan, hasil pengujian dapat dilihat pada Tabel 2.

\section{Kadar Lemak}

Lemak merupakan zat yang terkandung dalam bahan pangan, baik yang sudah diolah maupun belum diolah. meskipun kandungan yang dimiliki setiap bahan pangan berbeda-beda. Lemak 
sangat dibutuhkan oleh tubuh,lemak terbagi menjadi dua jenis, yaitu lemak hewani dan lemak nabati. Lemak hewani memiliki kandungan sterol atau yang biasa dikenal dengan kolestrol sedangkan lemak nabati memiliki kandungan fitosterol. Berdasarkan hasil pengujian pada Tabel 2. Menunjukan bahwa kandungan lemak yang terdapat pada kandungan flavor terpilih lebih tinggi dibandingkan lemak pada air rebusan kepala udang. adapun kadar lemak yang diperoleh yaitu $0,44 \pm 0,00 \%$. Kandungan lemak pada bahan pangan dapat mengalami penurunan, tergantung dari cara pengolahanya, semakin tinggi suhu yang diberikan maka kemunduran mutu kadar lemak akan semakin bervariasi, (Sundari et al. 2016).

\section{Kadar Protein}

Kadar protein merupakan hasil perhitungan gizi secara kasar yang mana protein merupakan zat makanan yang menjadi sumber gizi sangat dibutuhkan oleh tubuh. Fungsi dari protein ini yaitu sebagai zat pembangun dan zat pengatur bagi tubuh. Protein merupakan sumber asam-asam amino yang mengandung unsur-unsur karbon, hidrogen, oksigen, dan nitrogen, (Sundari et al. 2016). Cairan yang dikeluarkan dari dalm tubuh ikan pada saat perebusan mengandung beberapa zat gizi salah satunya adalah protein, (Viyanti et al. 2019). Namun proses pemasakan akan mempengaruhi kandungan gizi yang terdapat dalam bahan pangan tersebut. semakin lama proses pemasakan dan suhu yang digunakan juga tinggi maka kemunduran protein akan semakin cepat. Karena proses pengolahan dapat menyebapkan kandungan protein menjadi rendah hal inilah yang mempengaruhi kandungan protein flavor terpilih menjadi rendah, hasil pengujian dapat dilihat pada Tabel 2.

\section{Kadar Karbohidrat}

Karbohidrat merupakan sumber energi yang sebagian besar berasal dari senyawa organik sehingga sangat dibutuhkan oleh tubuh untuk memperlancar sistem metabolisme, cadangan makanan dan materi pembangun. Karbohidrat dapat mempengaruhi dari bentuk falvor yang dihasilkan, seperti pada warna, tekstur dan rasa, (Winarno 2008). Pada flavor air limbah rebusan ikan tamban ini memiliki kandungan karbohidrat yang cukup tinggi, yaitu mencapai $22,94 \%$ hampir mendekati penelitian Meiyani (2014). Karbohidrat dapat bersumber dari pati-patian dan dapat juga berasal dari biota itu sendiri. Biota yang memiliki kandungan karbohidrat tinggi dapat dipengaruhi dari siklus hidupnya. Pada penelitian sebelumnya dari tepung kepala dan tulang ikan tamban memiliki kandungan bahan ekstrak tanpa nitrogen (BETN) sebesar 22,74\%, (Miranti dan putra 2019). Hasil pengujian karbohidrat dapat dilihat pada Tabel 2.

\section{Asam Amino Flavor Terpilih}

Asam amino merupakan komponen terpenting bagi tubuh sehingga perlu untuk diperhatikan, tujuan dari pengujian asam amino ini yaitu untuk mengetahui jenis asam amino apa saja yang terdapat dalam flavor pasta dari air limbah rebuasan ikan tamban. Beberapa fungsi asam amino yaitu memperbaiki jaringan yang rusak setelah luka, melindungi hati dari berbagai zat toksik, menurunkan tekanan darah, mengatur metabolisme kolesterol, mendorong sekresi hormon pertumbuhan, dan mengurangi kadar amonia di dalam darah (Sari et al. 2017). 
Metode yang digunakan dalam analisis asam amino ini dengan menggunakan Ultra Performance Liquid Chromatography (UPLC), metode ini dilakukan dengan pemutusan ikatan hidrogen pada protein melalui hidrolisis asam.

Tabel 3. Kandungan asam amino daging keong bakau segar dan rebus

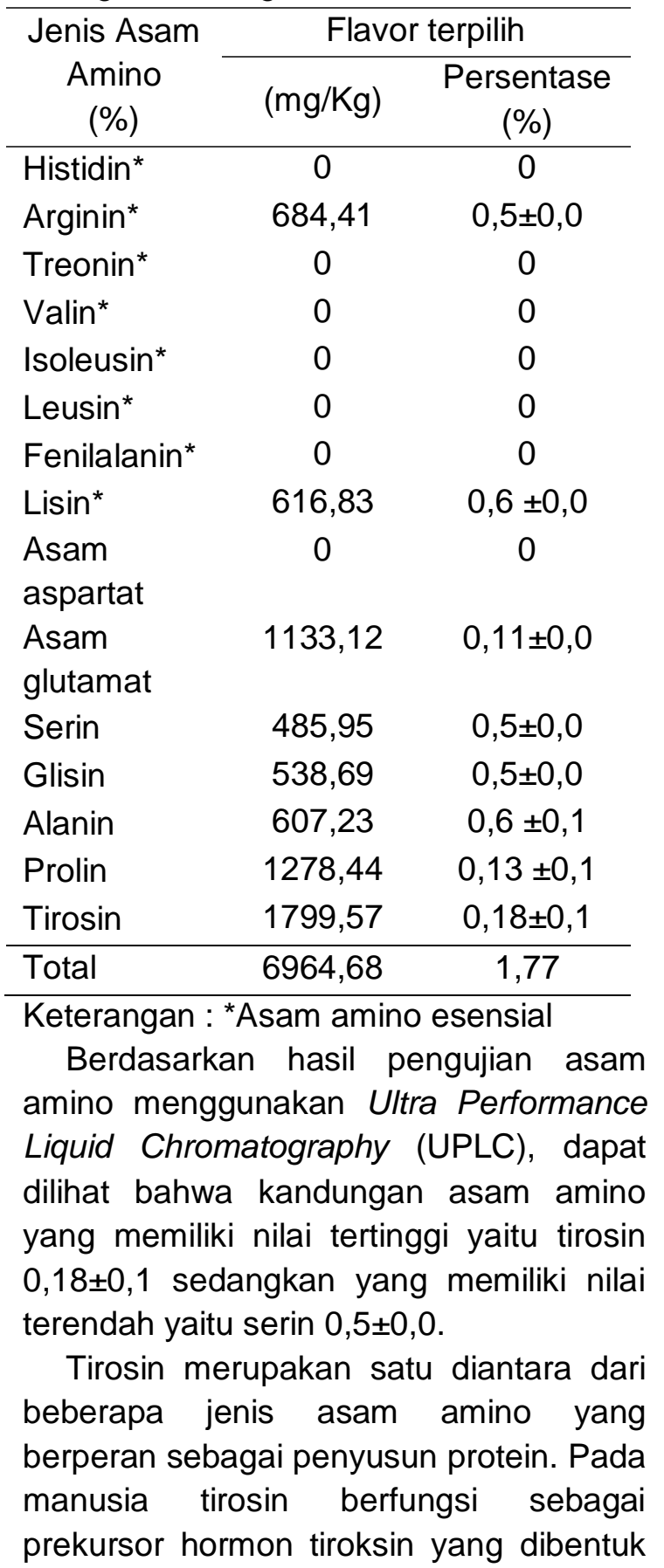

dalam kelenjar tiroid dan dapat meningkatkan nafsu makan. Tiroksin ini juga bersifat netral dan polar (hidrofilik) namun tidak bermuatan. Sedangkan serin sering ditemukan pada hewan, asam amino ini sangat penting bagi tubuh karena dapat mempengaruhi sistem metabolit.

Serin teridentifikasi sebagai stimulan kimia yang mempengaruhi tingkah laku makan pada ikan. Serin tergolong asam amino nonesensial, memiliki $\mathrm{pH}$ netral, polar tetapi tidak bermuatan dan struktur kimianya alifatik, (Rahayu et al. 2014). Peranya yang penting membuat jenis asam amino ini sangat perlu untk diperhatikan, karena sifatnya yang berperan sebagai biokatalisator (mempercepat reaksi) merupakan penyusun pada enzim. Pada manusia serin berfungsi dalam memproduksi antibodi dan immunoglobulin serta penting dalam metabolism lemak dan asam lemak.

\section{Logam Berat Air Limbah Perebusan}

Logam berat merupakan kelompok unsur yang memiliki masa jenis lebih besar dalam kondisi tertentu dapat membahayakan bagi yang mengkonsumsi, karena dapat bersifat toksik bila sudah berada diambang batas. Logam berat diantaranya yaitu timbal $(\mathrm{Pb})$, cadmium $(\mathrm{Cd})$, merkuri $(\mathrm{Hg})$. Logam berat diwilayah perairan dapat disebabkan oleh aktivitas manusia dilingkungan perairan yang tidak baik, seperti dengan adanya galangan kapal atau bahakan limbah industri rumah tangga yang terus menumpuk dengan ketidak sadaran manusia dalam menjaga ekosistem. laut yang sudah tercemar akan berdampak pada biota yang hidup disekitarnya, dan akan berbahaya bila dikonsumsi. logam berat timbal $(\mathrm{Pb})$ ini tidak dapat terurai dengan sendirinya di 
alam, sehingga berbahaya bila ada yang mengkonsumsinya dan jika keberadaanya melampaui batas maka akan menyebabkan kematian biota-biota yang ada disekitarnya.

Keracunan kadmium (Cd) kronis menyebabkan kerusakan pada fisiologis tubuh, yaitu ginjal, paru-paru, darah, jantung, kelenjar reproduksi, indera penciuman dan kerapuhan tulang, (Setiawan 2013). sedangkan Merkuri $(\mathrm{Hg})$ secara alami di perairan sangatlah sedikit. Merkuri berasal dari kegiatan gunung berapi, rembesan-rembesan air tanah yang melewati daerah yang mengandung merkuri, (Barus et al. 2016). Merkuri dapat kita jumpai seperti ditanah, air dan udara, mengkonsumsi merkuri tanpa disadari dan telah melampaui ambang batasnya dapat membahayakan bagi kesehatan.

Tabel 4. Hasil analisis kandungan logam berat $\mathrm{Pb}, \mathrm{Cd}$ dan $\mathrm{Hg}$ pada daging keong bakau segar dan rebus.

\begin{tabular}{crr}
\hline \multirow{2}{*}{$\begin{array}{c}\text { Logam } \\
\text { Berat }\end{array}$} & \multicolumn{2}{c}{$\begin{array}{c}\text { Air limbah perebusan } \\
\text { tamban }\end{array}$} \\
\cline { 2 - 3 } & Hasil uji & \multicolumn{1}{c}{$\begin{array}{c}\text { Ambang } \\
\text { batas }(\mathrm{ppm})\end{array}$} \\
\hline $\mathrm{Pb}$ & $\mathrm{Ttd}$ & $0.009^{*}$ \\
$\mathrm{Cd}$ & $\mathrm{Ttd}$ & $0.00011^{\star *}$ \\
$\mathrm{Hg}$ & $\mathrm{Ttd}$ & $0.004^{\star \star *}$ \\
\hline
\end{tabular}

(Ttd : tidak terdeteksi)

Berdasarkan hasil pengujian yang dilakukan bahwa air limbah rebusan ikan tamban tidak melewati mbang batas yang ditetapkan yaitu $\mathrm{Pb} 0.00011, \mathrm{Cg} 0,009$ dan $\mathrm{Hg} \mathrm{0,004}$. Hal ini disebabkan karena wilayah peraiaran tersebut masih dalam keadaan baik, hal ini karena diwilayah daerah pengambilan sampel tidak adanya seperti industri galangan kapal dan aktivitas kapal-kapal juga masih dalam keadaan yang normal (tidak melampaui batas). Kandungan logam berat yang kecil pada suatu organisme disebabkan oleh beberapa faktor, antara lain yaitu perbedaan dari laju pertumbuhan, kecepatan metabolisme tubuh, dan tingkat sensivitas tubuh terhadap pemasukan logam berat tertentu dan kebutuhan fisiologis terhadap logam (Nurrachmi et al. 2011).

\section{Viskositas}

Viskositas merupakan tingkat kekentalan yang dimiliki suatu produk karena adanya faktor suhu, seperti pemanasan, dan pendinginan. dalam pembuatan flavor pasta dari air limbah rebusan ikan air tamban ini akan memiliki tingkat kekentalan yang lebih tinggi, bila dipanaskan suhu tinggi dan waktu pemanasan yang lebih lama. Selain suhu tingkat kekentalan juga dipengaruhi oleh xanthan gum, gum ini mampu menjaga kestabilan flavor baik pada kondisi membeku/mencair. Sifat ini yang tidak dimiliki oleh gum-gum lainnya, (Wandestri et al. 2016).

Tabel 5. Hasil Uji viskositas flavor pasta terpilih

\begin{tabular}{lll}
\hline Parameter & $\begin{array}{l}\text { Hasil uji } \\
\text { flavor } \\
\text { terpilih }\end{array}$ & $\begin{array}{l}\text { Pembanding } \\
\text { hasil uji }\end{array}$ \\
\hline Viskositas & $\begin{array}{l}19.200 \\
\text { (cP) }\end{array}$ & $11764^{*}$ \\
\hline
\end{tabular}

Keterangan: *Kekentalan saos tomat

(Wandestri et al. 2016)

Berdasarkan hasil pengujian viskositas yang menggunakan alat viskometer brokfield maka tingkat kekentalan pasta flavor air limbah rebusan ikan tamban memiliki tingkat kekentalan yang lebih tinggi dibandingkan dengan penelitian (Wandestri et al 2016). Perbedaan tingkat kekentalan dipengaruhi oleh konsentrasi xanthan gum yang digunakan, wandestri 
menggunakan $0,4 \%$ sedangkan falvor air limbah rebusan ikan tamban hanya menggunakan $0,3 \%$. Selain itu juga dipengaruhi oleh suhu yang stabil yaitu pada suhu $80 \stackrel{\circ}{\circ}$, semakin dekat rentang suhu yang diberikan akan semakin tampak perbedaan bentuk flavor yang dihasilkan.

\section{KESIMPULAN}

Suhu memiliki peranan penting dalam pengulahan flavor pasta yang dihasilkan, karena akan mepengaruhi tehadapa warna, aroma, rasa dan tekstur yang dihasilkan, berdasarkan uji organoleptik maka flavor pasta terpilih yaitu F3 dengan perlakuan suhu $80 \stackrel{\circ}{\circ}$. Kandungan yang terdapat didalamnya yaitu protein $0,76 \%$, kadar air 62,44\%, kadar abu 13,42\%, karbohidrat 22,94\%. Asam amino yang diperoleh dengan nilai tertinggi yaitu Tirosin $0,18 \%$ dan yang memiliki nilai terendah yaitu serin $0,04 \%$. Setelah dilakukan uji logam berat pada bahan baku flavor masih dikategorikan aman untuk dikonsumsi karena logam berat tidak terdeteksi yang dapat dikategorikan wilayah perairan Desa Pangkil masih dalam kondisi yang baik. Sehingga air limbah rebusan ikan tamban ini bisa dijadikan sebagai bahan baku pembuatan flavor alami dengan suhu optimal yaitu 80 $\stackrel{\circ}{ } \mathrm{C}$.

\section{DAFTAR PUSTAKA}

[BSN] Badan Standarisasi Nasional. 1992. Uji Proksimat (SNI 01-28911992). BSN, Jakarta.

Anggraini. Aridita., Yunianta. 2015. Pengaruh Suhu Dan Lama Hidrolisis Enzim Papain Terhadap Sifat Kimia, Fisik Dan Organoleptik Sari Edamame. Jurnal Pangan dan Agroindustri. Vol. 3(3):1015-1025.
Badan Standarisasi Nasional. 2006a. SNI 01-2346-2006: Petunjuk Pengujian Organoleptik dan atau Sensori. Jakarta: Badan Standarisasi Nasional. $23 \mathrm{hlm}$.

Barus. B. S. 2017. Analisis Kandungan Logam Berat Kadmium (Cd) Dan Merkuri (Hg) Pada Air Dan Sedimen Di Perairan Muara Sungai Banyuasin. Maspari Jurnal. Vol. 9(1):69-76.

Bassey SCO, Eteng MU, Eyong EU, Ofem OE, Akunyoung EO, Umoh IB. 2011. Comparative nutritional and biochemical evaluation of Ergeria radiata (clams) and Pomecia palludosa (gastropods). Research Journal of Agriculture and Biological Sciences. 7(1): 98- 104.

Fajrita I., Junianto., Sriati. 2016. Tingkat Kesukaan Petis Dari Cairan Hasil Pemindangan Bandeng Dengan Penambahan Tepung Tapioka Yang Berbeda. Jurnal Perikanan Kelautan. Vol. 7(2): 121-127.

Lakshmi, G.C. 2014. Food Coloring: The Natural Way. Research Journal of Chemical Sciences 4(2): 87-96

Mega. O. 2008. Komposisi Nutrisi Pasta Berbahan Baku Nikumi Kuda dan Sapi. Jurnal Sain Peternakan Indonesia Vol. 3(2):93-100.

Meiyani. D. N. A. T., Riyadi. P. H., Anggo. A. D. 2014. Pemanfaatan Air Rebusan Kepala Udang Putih (Penaeus merguiensis) Sebagai Flavor Dalam Bentuk Bubuk Dengan Penambahan Maltodekstrin. Jurnal Pengolahan dan Bioteknologi Hasil Perikanan. Vol. 3(2):67-74.

Miranti, S., Putra,W.K.A. 2019. Uji Potensi Limbah Ikan dari Pasar Tradisional di Kota Tanjungpinang sebagai Bahan Baku Alternatif Pembuatan Pakan untuk Budidaya Ikan Laut. Intek Akuakultur. Vol.3(1): 8-15. 
Mulyadi AF, Maligan JM, Wignyanto dan Hermansyah R. 2013. Karakteristik organoleptik serbuk perisa alami dari cangkang rajungan (Portunus pelagicus) Kajian dekstrin dan suhu pengeringan. Jurnal Teknologi Pertanian. Vol. 14(3): 183-192.

Negara. J. K., Sio. A. K., Rifkhan, Arifin M., Oktaviana. A. Y., Wihansah R. R. S., Yusuf. M. 2016. Aspek Mikrobiologis serta Sensori (Rasa, Warna, Tekstur, Aroma) pada Dua Bentuk Penyajian Keju yang Berbeda. Jurnal IImu Produksi dan Teknologi Hasil Peternakan. Vol. 04 (2): 286-290.

Nilasari. O. W., Susanto. W. H., Maligan J. M. 2017. Pengaruh Suhu Dan Lama Pemasakan Terhadap Karakteristik Lempok Labu Kuning (Waluh). Jurnal Pangan dan Agroindustri Vol.5(3):1526.

Nurjanah., Jacoeb A. M., Fetrisia R. G. 2013. Komposisi Kimia Kerang Pisau (Solens sp.) Dari Pantai Kejawanan, Cirebon, Jawa Barat. Jurnal Pengolahan Hasil Perikanan Indonesia. Vol. 16(1):22-32.

Nurrachmi, I., B. Amin., M. N. Habibi. 2011. Bioakumulasi Logam $\mathrm{Cd}, \mathrm{Cu}, \mathrm{Pb}$ dan Zn Pada Beberapa Bagian Tubuh Ikan Gulama (Sciaena russelli) dari Perairan Dumai Riau. Jurnal Maspari . 2(1): 01-10.

Rahayu, M., Pramonowibowo \& Taufik. Y. 2014. Profil asam amino yang terdistribusi ke dalam kolom air laut pada ikan Kembung (Rastrelliger kanagurta) sebagai umpan skala laboratorium. Journal of fisheries Resources Utilization Management and Technology. 3(3): 238-247.

Sari. E.M., Nurilmala M., Abdullah. A. 2017. Profil Asam Amino Dan Senyawa Bioaktif Kuda Laut Hippocampus comes. Jurnal IImu dan
Teknologi Kelautan Tropis. Vol. 9(2):605-617.

Setiawan. H. 2017. Akumulasi Dan Distribusi Logam Berat Pada Vegetasi Mangrove Di Perairan Pesisir Sulawesi Selatan. Jurnal IImu Kehutanan. Vol. 7(1):12-24.

Sundari. D., Almasyhuri., Lamid. A. 2015. Pengaruh Proses Pemasakan Terhadap Komposisi Zat Gizi Bahan Pangan Sumber Protein. Media Litbangkes. Vol. 25(4):235-242.

Supriyanti, Florentina Maria Titin, Gebi Dwiyanti, Puspa Dwipa Muliani. (2013). Surimi dari Ikan Beloso (Saurida tumbil Sp.) dan Analisis Kandungan Gizinya. Jurnal Sains dan Teknologi Kimia. 4 (2):125-134.

Suryana. M. A., Patadjai. A. B., Asyik. N. 2016. Pengaruh Pemakaian Cryoprotectant Berbeda Terhadap Sensorik Dan Kualitas Kimia Surimi Dari Ikan Lele Dumbo (Clarias gariepinus). Jurnal Sains dan Teknologi Pangan. Vol. 1(3):175-183.

Viyanti. R., Sumardianto., Suharto S. 2019. Penggunaan Air Pindang Ikan Berbedaterhadap Kandungan Asam Glutamat Pada Petis. PENA Akuatika. Vol. 18(2):23-33.

Winarno FG. 2008. Kimia Pangan dan Gizi. Jakarta: PT. Gramedia Pustaka Utama.

Winarno FG. 2008. Kimia Pangan dan Gizi. Jakarta: PT. Gramedia Pustaka Utama. 